\section{ACHILLES TENDON OF WISTAR RATS TREATED WITH LASER THERAPY AND ECCENTRIC EXERCISE}

\author{
TENDÃO CALCANEAR DE RATOS WISTAR TRATADOS COM LASERTERAPIA E EXERCÍCIO EXCÊNTRICO
}

TENDÓN DE AQUILES DE RATAS WISTAR TRATADOS CON LASERTERAPIA Y EJERCICIO EXCÉNTRICO

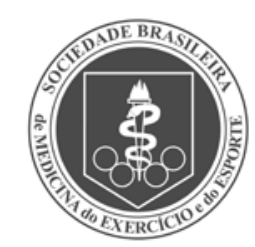

Original Article ARTIGo ORIGINAL Artículo Original
Maria Verônica de Souza' (Médica Veterinária)

Carlos Henrique Osório Silva (Agrônomo)

Micheline Ozana da Silva' (Fisioterapeuta)

Marcela Bueno Martins da Costa (Médica Veterinária)

Raul Felipe Dornas ${ }^{1}$ (Médico Veterinário)

Andréa Pacheco Batista Borges ${ }^{1}$ (Médica Veterinária)

Antônio José Natali ${ }^{1}$

(Educador Físico)

1. Universidade Federal de Viçosa (UFV), Viçosa, MG, Brazil.

\section{Correspondence:}

Universidade Federal de Viçosa, Departmento de Veterinário. Av. PH Rolfs, s/n, 36570-900 Viçosa, $M G$, Brazil.

msouza@ufv.br, msouzavet@gmail.com

\begin{abstract}
Introduction: Both laser therapy and eccentric exercises are used in tendon injuries. However, the association of these physiotherapeutic modalities is yet little investigated. Objective: To evaluate the effect of low-level laser therapy associated to eccentric exercise (downhill walking) on Achilles tendinopathy of Wistar rats. Method: Eighteen Achilles tendon from 15 adult male Wistar rats were used. Tendons were distributed in six groups (laser, eccentric exercise, laser and eccentric exercise, rest, contralateral tendon, and healthy tendon). Unilateral tendinopathy was surgically induced by transversal compression followed by scarification of tendon fibers. The treatments laser therapy $\left(904 \mathrm{~nm}, 3 \mathrm{~J} / \mathrm{cm}^{2}\right.$ ) and/or eccentric exercise (downhill walking; $12 \mathrm{~m} / \mathrm{min} ; 50 \mathrm{~min} / \mathrm{day}$; $15^{\circ}$ inclination treadmill) began 24 hours after surgery and remained for 20 days. Clinical and biomechanical analyzes were conducted. Achilles tendon was macroscopically evaluated and the transversal diameter measured. Euthanasia was performed 21 days after lesion induction. Tendons of both limbs were collected and frozen at $-20^{\circ} \mathrm{C}$ until biomechanical analysis, on which the characteristic of maximum load (N), stress at ultimate (MPa) and maximum extension (mm) were analyzed. Results: Swelling was observed within 72 hours postoperative. No fibrous adhesions were observed nor increase in transversal diameter of tendons. Animals with the exercised tendons, but not treated with laser therapy, presented lower $(p=0.0000)$ locomotor capacity. No difference occurred between groups for the biomechanical characteristics maximum load $(p=0.4379)$, stress at ultimate $(p=0.4605)$ and maximum extension ( $p=0.3820$ ) evaluated, even considering healthy and contralateral tendons. Conclusion: The concomitant use of low-level laser and the eccentric exercise of downhill walking, starting 24 hours after surgically induced tendinopathy, do not result in a tendon with the same biomechanical resistance or elasticity as a healthy tendon. On the other hand, it also does not influence negatively the structure and function of the Achilles tendon.
\end{abstract}

Keywords: low-level laser therapy; tensile strength; treadmill test.

\section{RESUMO}

Introdução: Tanto a laserterapia como exercícios excêntricos são utilizados em lesões tendíneas. Entretanto, a associação dessas modalidades fisioterapêuticas aindaé pouco investigada. Objetivo: Avaliar o efeito da terapia com laser de baixa potência associada a exercício excêntrico (caminhada em declive) na tendinopatia do tendão calcanear de ratos Wistar. Método: Foram utilizados 18 tendões calcaneares provenientes de 15 ratos Wistar machos adultos. Os tendões foram distribuídos em seis grupos (laser, exercício excêntrico, laser e exercício excêntrico, repouso, tendão contralateral e tendão sadio). A tendinopatia unilateral foi cirurgicamente induzida mediante compressão transversal seguida pela escarificação das fibras tendíneas. Os tratamentos de laserterapia $\left(904 \mathrm{~nm}, 3 \mathrm{~J} / \mathrm{cm}^{2}\right.$ ) e/ou exercício excêntrico (caminhada em declive; $12 \mathrm{~m} / \mathrm{min} ; 50 \mathrm{~min} /$ dia; esteira com $15^{\circ}$ de inclinação) se iniciaram 24 horas após a cirurgia e permaneceram por 20 dias. Foram conduzidas análises clínica e biomecânica. O tendão calcanear foi examinado macroscopicamente, e seu diâmetro transversal mensurado. Eutanásia foi realizada 21 dias após indução da lesão. Os tendões de ambos os membros foram obtidos e congelados $a-20^{\circ} \mathrm{C}$ até realização da análise biomecânica, na qual foram testadas as características de carga máxima $(\mathrm{N})$, tensão na carga $(\mathrm{MPa})$ e extensão $(\mathrm{mm})$ máxima. Resultados: Edema local foi observado nas primeiras 72 horas do pós-operatório. Não foram observadas aderências fibrosas, nem aumento no diâmetro transversal dos tendões. Animais com tendões exercitados, porém não tratados com laserterapia, apresentaram menor $(p=0,0000)$ capacidade de locomoção. Não houve diferença entre grupos nas características biomecânicas de carga máxima $(p=0,4379)$, tensão na carga $(p=0,4605)$ e extensão máxima $(p=0,3820)$, inclusive considerando-se tendões sadios e contralaterais. Conclusão: A utilização concomitante de laser de baixa potência e exercício excêntrico de caminhada em declive, iniciados 24 horas após tendinopatia induzida cirurgicamente, não resulta em um tendão biomecanicamente tão resistente ou elástico quanto um tendão saudável. Por outro lado, também não influencia negativamente na estrutura e função do tendão calcanear.

Palavras-chave: terapia a laser de baixa potência, resistência à tração, teste ergométrico de esteira.

\section{RESUMEN}

Introducción: Tanto la laserterapia como ejercicios excéntricos son utilizados en lesiones tendíneas. Entretanto, la asociación de esas modalidades fisioterapéuticas aún es poco investigada. Objetivo: Evaluar el efecto de la terapia con láser de baja potencia asociada a ejercicio excéntrico (caminata en declive) en la tendinopatía del tendón de 
Aquiles de ratas Wistar. Método: Fueron utilizados 18 tendones de Aquiles provenientes de 15 ratas Wistar machos adultos. Los tendones fueron distribuidos en seis grupos (láser, ejercicio excéntrico, láser y ejercicio excéntrico, reposo, tendón contralateral y tendón sano). La tendinopatía unilateral fue quirúrgicamente inducida mediante compresión transversal seguida por la escarificación de las fibras tendíneas. Los tratamientos de laserterapia (904 nm, 3J/ $\mathrm{cm}^{2}$ ) y/o ejercicio excéntrico (caminata en declive; $12 \mathrm{~m} / \mathrm{min} ; 50 \mathrm{~min} /$ dia; cinta con $15^{\circ}$ de inclinación) se iniciaron 24 horas después de la cirugía y permanecieron por 20 días. Fueron conducidos análisis clínico y biomecánico. El tendón de Aquiles fue examinado macroscópicamente, y su diámetro transversal medido. Fue realizada eutanasia 21 días después de la inducción de la lesión. Los tendones de ambos miembros fueron obtenidos y congelados a $-20^{\circ} \mathrm{C}$ hasta la realización del análisis biomecánico, en el que fueron probadas las características de carga máxima $(\mathrm{N})$, tensión en la carga (MPa) y extensión $(\mathrm{mm})$ máxima. Resultados: Fue observado edema local en las primeras 72 horas del postoperatorio. No fueron observadas adherencias fibrosas, ni aumento en el diámetro transversal de los tendones. Los animales con tendones ejercitados, aunque no tratados con laserterapia, presentaron menor $(p=0,0000)$ capacidad de locomoción. No hubo diferencia entre grupos en las características biomecánicas de carga máxima $(p=0,4379)$, tensión en la carga $(p=0,4605)$ y extensión máxima $(p=0,3820)$, incluso considerándose tendones sanos y contralaterales. Conclusión: El uso concomitante de láser de baja potencia y ejercicio excéntrico de caminata en declive, iniciados 24 horas después de la tendinopatía inducida quirúrgicamente, no resulta en un tendón biomecánicamente tan resistente o elástico cuanto un tendón sano. Por otro lado, tampoco influencia negativamente en la estructura y función del tendón de Aquiles.

Palabras clave: terapia a láser de baja potencia, resistencia a la tracción, test ergométrico de cinta.

\section{INTRODUCTION}

The terminology tendinopathy is used to define several painful conditions that affect the tendons, which are accompanied by pain, swelling, loss of function, as well as changes in tissues adjacent to joints, where the tendinous structure runs its anatomical course. Tendons play an important role in musculoskeletal system by transferring tensile loads from muscle stabilizing joints and, therefore, allowing appropriate movement of the limbs ${ }^{1}$. They also have the ability to undergo mechanical adaptation in response to forces by change their structure, composition and mechanical properties. In contrast, an abnormal adaptation to these loads can lead to tendinopathy ${ }^{2}$, which can be associated with several both intrinsic and extrinsic factors to the tendon (age, genetics, vascular supply ${ }^{3}$ ). Once injured, depending on the severity, it may take months for complete tendon healing. Nevertheless, the biomechanical characteristics may not return to normality ${ }^{4}$. Thus, the search for therapeutic procedures that promote faster healing and better quality of tendons has been the purpose of various studies. In this context, low-level laser is a therapy used in tendon injuries, for promoting analgesia ${ }^{5}$, and for stimulating collagen ${ }^{6}$ and growth factors synthesis, as well as angiogenesis. According to some authors, the therapy allows faster tissue healing ${ }^{7}$, with appropriate structural organization of collagen fibers ${ }^{8}$.

Controlled physical activity is also considered an important alternative not only for prevention, but also as a form of treating tendinopathies. Among the used activities, those that use exercises with eccentric contraction stand out, where the force generated by the muscle is not sufficient to support the load imposed to it. Thus, muscle fibers stretch out and elongate when contracting, which results in important physiological adaptations in strength and muscle mass. The downhill walking is a type of eccentric exercise that improves the tendon structure and increases the collagen production. These features promote a better quality of repair tissue, leaving the closest of its normal characteristics.

The present study hypothesizes that the association of laser therapy with controlled eccentric exercise results in a more resistant and less stiff tendon. Therefore, the purpose of this study was to evaluate by clinical and biomechanical analyzes the response to low-level laser therapy (GaAs $904 \mathrm{~nm}$ ) associated with eccentric exercise on tendinopathy of Achilles tendon of Wistar rats.

\section{MATERIAL AND METHODS}

This research was approved by the Ethics Committee on Animal Use of Universidade Federal de Viçosa (UFV) (protocol no. 108/2011).

Eighteen Achilles tendons, from 15 male adult Wistar rats (Rattus norvegicus) at age between 12 and 14 weeks, and body weight ranging between 300 and $350 \mathrm{~g}$ were used. Only animals with physical integrity of the locomotor system were included in the study after physical examination of sensitivity to pain and locomotion capacity (table 1).

The observation of abnormalities in "spontaneous" behavior related to sensitivity to pain was evaluated by a subjective scale, classified from 0 to $5^{9}$. The motor capacity was evaluated with scores that ranged

Table 1. Behavior tests based on sensitivity to pain and locomotor capacity.

\begin{tabular}{|c|c|}
\hline Scores & Physical evaluation \\
\hline & Sensitivity to Pain (according to Attal et al. ${ }^{9}$ ) \\
\hline 0 & Absent (distal region of limb - paw - is pressed normally on the floor) \\
\hline 1 & $\begin{array}{c}\text { Discrete (distal region of limb rests lightly on the floor, } \\
\text { and the toes are in a ventroflexed position) }\end{array}$ \\
\hline 2 & $\begin{array}{l}\text { Discrete to moderate (only the internal edge of limb distal } \\
\text { region is pressed on the floor) }\end{array}$ \\
\hline 3 & $\begin{array}{l}\text { Moderate (only the talocalcaneal region is pressed on floor, } \\
\text { and the paw is in an inverted position) }\end{array}$ \\
\hline 4 & Moderate to intense (the whole distal region is elevated) \\
\hline \multirow[t]{2}{*}{5} & Intense (the animal licks the operated paws) \\
\hline & Locomotor Capacity (according to Silva ${ }^{10}$ ) \\
\hline 0 & Absence of hindlimb movement; non-weight bearing \\
\hline 1 & Subtle movement, disconnected of the hindlimb; non-weight bearing \\
\hline 2 & Visible movement of hindlimb; non-weight bearing \\
\hline 3 & Supports load in hindlimb, however waking with deficit accentuated \\
\hline 4 & Walking with a moderate difficulty \\
\hline 5 & Walking with a discrete deficit, and cannot walk on $7.7 \mathrm{~cm}$ wide bar \\
\hline 6 & Normal walking or discrete deficit, and can walk on $7.7 \mathrm{~cm}$ wide bar \\
\hline 7 & Can walk on $6.7 \mathrm{~cm}$ wide bar \\
\hline 8 & Can walk on $5.7 \mathrm{~cm}$ wide bar \\
\hline 9 & Can walk on $4.7 \mathrm{~cm}$ wide bar \\
\hline 10 & Can walk on $3.7 \mathrm{~cm}$ wide bar \\
\hline 11 & Can walk on $2.7 \mathrm{~cm}$ wide bar \\
\hline 12 & Can walk on $1.7 \mathrm{~cm}$ wide bar \\
\hline
\end{tabular}


from 0 to $121^{10}$, where the higher the score the closer the animal was to normality. For this evaluation, spontaneous activity of animals was observed, with respect to the movement of hindlimbs and deambulation. Initially, the animals were individually placed in a $1.5 \mathrm{~m}$ length by $0.5 \mathrm{~m}$ width space, for observation of gait (including lameness) and, in the sequence they were submitted to a more specific evaluation in wooden bars. For this, six bars were used, each one with $1 \mathrm{~m}$ length, and widths of $7.7 ; 6.7 ; 5.7 ; 4.7 ; 3.7 ; 2.7$ and $1.7 \mathrm{~cm}$. All rats walked each bar twice, from the widest bar to the narrowest one.

During one week the animals were housed in individual cages, for acclimatization conditions of approximately $26^{\circ} \mathrm{C}$, and were maintained on a 12 hours daily photoperiod. All rats moved freely inside the cage, receiving industrial ration, and water ad libitum.

The tendons were randomly distributed in six groups $(L, E, L E, R, H$ and $(\mathrm{L})$ containing three tendons in each one of them. Group " $\mathrm{L}$ " was composed by animals submitted to laser therapy, whereas group "E" to the eccentric exercise treadmill walking. Group "LE" tendons were submitted to both laser therapy and treadmill walking, whereas the group " $\mathrm{R}$ " rested during the whole healing process of tendons. Group " $\mathrm{H}$ " animals had complete integrity of tendons, in other words, were healthy, and group "CL" was formed by contralateral limb to the injured tendon of groups R, E and LE (randomly chosen). Animals of groups $E$ and $R$ were handled as if they were going to receive radiation; however the equipment was kept disconnected.

The surgical induction of unilateral tendinopathy (randomly chosen) was based to the protocol described by Silva et al. ${ }^{11}$ by transversal compression of whole thickness during 10s with Halstead forceps (the second ratchet), followed by 10 proximal-distal ward scarifications of the tendon fibers using a scalpel blade.

A single dose of enrofloxacin (40 mg/kg intramuscularly), as well as morphine ( $3 \mathrm{mg} / \mathrm{kg}$, subcutaneously) was administered every 6 hours for 12 hours. During the postoperative period, the wounds were daily cleaned with gauze soaked in running water.

Groups $L$ and $L E$ tendons received gallium arsenide (GaAs) low-level laser therapy. The application was carried out punctually, and in pulse mode during nine $9 \mathrm{~s} /$ day, with a laserpulse equipment (Ibramed Indústria Brasileira de Equipamentos Medicos Ltda, Amparo, SP, Brazil). A $904 \mathrm{~nm}$ wavelength, $3 \mathrm{~J} / \mathrm{cm}^{2}$ energy density and $100 \mathrm{~mW} / \mathrm{cm}^{2}$ power were used. The treatment began 24 hours after injury induction, being applied daily for 20 days. During laser application, animals were manually immobilized and positioned in ventral decubitus. The device was positioned perpendicular to the injury, and the radiation was always done at the same time, observing an interval of 24 hours between applications, as described by Silva et al. ${ }^{12}$

Groups $\mathrm{E}$ and LE tendons were submitted to daily controlled eccentric exercise, from 24 hours after tendinopathy induction. A treadmill (Insight Pesquisa e Ensino Ltda, São Paulo, SP, Brazil) walking protocol during a period of three weeks was adopted, which was modified from those described by Nakamura et al. ${ }^{13}$, who used eccentric exercise for a longer period (60 min) and speed (15 m/s).

With the purpose of prior adaptation to the exercise, the animals were exercised for seven consecutive days before surgical induction of injury. Speed was set to $12 \mathrm{~m} / \mathrm{min}$, for a $50 \mathrm{~min} /$ day, both during the adaptation period and in the experimental one. The treadmill was kept at $15^{\circ}$ inclination, and animals walked downhill. The eccentric exercise was carried out in a calm environment, with little lighting and at room temperature of approximately $25^{\circ} \mathrm{C}$.

After tendinopathy induction and during the realization of treatments, rats were submitted to physical evaluation of injury site and behavior tests described in Table 1. The first examination was performed
12 hours after surgery and the others every three days for 20 days. Twenty-four observations were performed during the behavior tests, i.e., eight evaluations with three tendons (replicates) in each group. The local examination consisted of evaluation for presence of swelling. Initially it was observed if there was volume increase in the surgery site, and immediately after euthanasia, the transverse diameter of tendon was verified using a caliper rule, positioned in the middle point of the tendon between the myotendinous junction and its insertion in the calcaneal bone ${ }^{14}$

Tendon samples were obtained from animals in the different groups for biomechanical evaluation, by tensile testing of Achilles tendon during the proliferative phase of the tendon healing process. For that, rats were euthanized (sodium thiopental, $100 \mathrm{mg} / \mathrm{kg}$, intraperitoneally ${ }^{15}$ ) at 21 days after beginning of treatments. After euthanasia and exposing of Achilles tendon, the existence or not of adhesions was verified between the tendon and the skin and/or adjacent tissues. In addition, the transverse diameters of tendons were evaluated.

Achilles tendons of the injured and contralateral limbs were dissected and subsequently removed, maintaining its insertion in the calcaneal bone. Next, the tendons together with the distal limb were involved in gauzes and placed in plastic containers containing $0.9 \%$ $\mathrm{NaCl}$ and frozen at $-20^{\circ} \mathrm{C}$ until biomechanical testing.

For biomechanical analysis, limbs were defrosted under running water and dissected, so that the tendon was fixed in its origin to a small region where the gastrocnemius and soleus muscles are located and in its insertion with the whole region denominated "paw". A tendon fragment of approximately $1 \mathrm{~cm}$ was tested to failure using a computer-controlled tissue testing devise (Instron Brasil, Tocantins, Barueri, SP, Brazil), which provided a tendon strain diagram.

The tendon was clamped and then load to failure was carried out at a strain rate of $0.5 \mathrm{~mm} / \mathrm{s}^{16}$, and the distance between the claws was $6 \mathrm{~mm}$. The variables maximum load (N), stress at maximum load (MPa) and maximum extension ( $\mathrm{mm}$ ) were measured.

The experiment was arranged in a completely randomized design with six treatments and three replicates (tendons), evaluated at 21 days after injury induction. The amount of tendons per group was the minimum necessary to conduct the research, and allowed to conduct inferential analysis with an appropriate number of degrees of freedom for the residuals of the analysis of variance (ANOVA). For physical and macroscopic evaluations, the contralateral and healthy groups were not considered. Data were initially submitted to descriptive analysis, and to Lilliefors and Cochran tests for normality and homogeneity of variance, respectively. ANOVA was used to check the effects of treatments on clinical and biomechanics analyzes. Treatments were compared by Tukey test at 5\% probability. The analyses were carried out with the Statistica 12, 2013 software (www.statsoft.com).

\section{RESULTS}

Throughout the experimental period, no limbs presented signs of infection. In the first evaluation, carried out 12 hours after tendinopathy induction, discrete intensity swelling in injured limbs was observed, which was maintained up to 72 hours. There was no tissue adherence or increase of transverse diameter of tendons $(p=0.5820) 21$ days after surgery, when these characteristics were evaluated.

During evaluation of sensitivity to pain, rats apparently presented no signs of discomfort, and maintained normal hindlimb posture. Therefore, all rats received score 0 (absente) for classification of sensitivity to pain adopted in the study. Conversely, locomotor capacity evaluation revealed discrete lameness in all animals up to 72 hours after tendinopathy induction, observed during deambulation in open field. 
There was difference $(p=0.0000)$ between groups for this characteristic (table 2). The exercised tendons, but not treated with laser therapy, presented lower locomotor capacity than the others, since rats were unable to move on bars with 2.7 and $1.7 \mathrm{~cm}$ width. The mean values for group are shown in figure 1.

Two animal from the resting group (during all evaluated times), one rat from the tendon treated with laser (from the sixth evaluation) and another one that received laser combined with eccentric exercise (from the third evaluation) were able to move on the bar $1.7 \mathrm{~cm}$ width.

All tendons submitted to biomechanical analysis ruptured in the myotendinous junction. Although the obtained values have demonstrated that tendons treated with laser and eccentric exercise needed higher load (26.59 $\pm 19.63 \mathrm{~N})$, and stress (2.25 $\pm 1.67 \mathrm{MPa}$ ) to rupture, there was no difference between groups evaluated for variables biomechanical maximum extension ( $p=0.3820$ ) and load ( $p=0.4379)$, as well as stress at maximum load ( $p=0.4605$ ) (table 3 ).

Table 2. Mean and standard deviation values for locomotor capacity scores of animals from different groups 21 days after tendinopathy induction.

\begin{tabular}{c|c|c}
\hline Groups & Scores & Locomotor capacity \\
\hline Rest & $11.04 \pm 1.49 \mathrm{a}$ & Walked up to $2.7 \mathrm{~cm}$ wide bar \\
\hline Eccentric exercise & $9.96 \pm 1.00 \mathrm{~b}$ & Walked up to $3.7 \mathrm{~cm}$ wide bar \\
\hline Laser & $11.67 \pm 0.76 \mathrm{a}$ & Walked up to $2.7 \mathrm{~cm}$ wide bar \\
\hline Laser and eccentric exercise & $11.29 \pm 0.91 \mathrm{a}$ & Walked up to $2.7 \mathrm{~cm}$ wide bar \\
\hline
\end{tabular}

Means followed by the same letter do not differ statistically $(p>0.05)$ by Tukey Test.

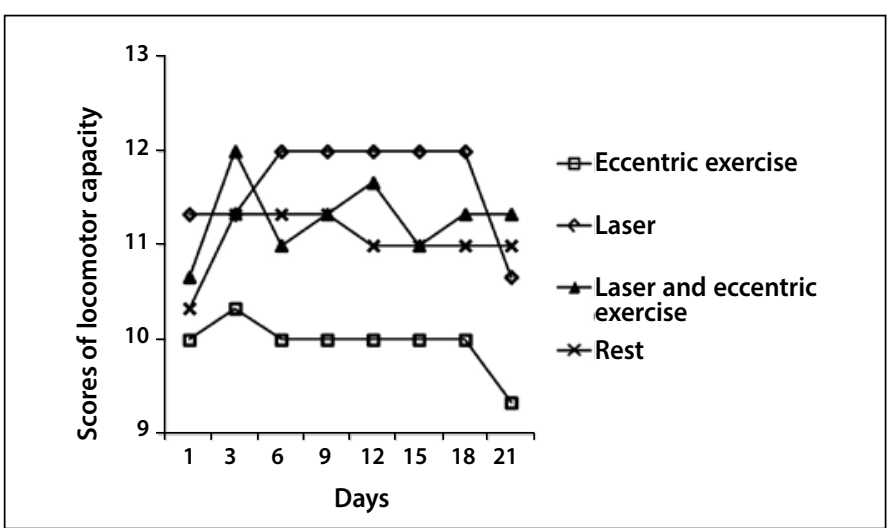

Figure 1. Locomotor capacity average scores over time for each treatment group. Note that the group submitted to eccentric exercise performed during the experimental period showed less walking ability, unlike the group submitted only to laser therapy.

Table 3. Mean and standard deviation values for characteristic evaluated in biomechanical analysis carried out 21 days after tendinopathy induction.

\begin{tabular}{c|c|c|c}
\hline Groups & $\begin{array}{c}\text { Maximum load } \\
(\mathbf{N})\end{array}$ & $\begin{array}{c}\text { Stress at } \\
\text { maximum load } \\
(\mathbf{M P a})\end{array}$ & $\begin{array}{c}\text { Maximum } \\
\text { extension }(\mathbf{m m})\end{array}$ \\
\hline Rest & $20.53 \pm 6.09$ & $1.77 \pm 0.53$ & $9.14 \pm 1.69$ \\
\hline Eccentric Exercise & $25.47 \pm 20.10$ & $2.16 \pm 1.71$ & $8.96 \pm 0.98$ \\
\hline Laser & $15.31 \pm 7.97$ & $1.30 \pm 0.68$ & $9.16 \pm 2.26$ \\
\hline Laser and eccentric exercise & $26.59 \pm 19.63$ & $2.25 \pm 1.67$ & $6.99 \pm 2.26$ \\
\hline Contralateral & $35.15 \pm 1.76$ & $2.96 \pm 0.13$ & $9.29 \pm 1.03$ \\
\hline Healthy & $34.33 \pm 11.68$ & $2.87 \pm 0.95$ & $7.33 \pm 1.19$ \\
\hline
\end{tabular}

\section{DISCUSSION}

The local swelling observed for 72 hours was expected due to the surgical trauma. The reduction of swelling in tendons submitted to eccentric exercise may be associated with the intensity of the treatment, since according to Lana et al. ${ }^{17}$, can influence the edema volume in the acute phase of the injury. According to the authors, high-intensity exercise causes increased IL-6. However, despite this cytokine trigger a pro-inflammatory effect, it is also related to an anti-inflammatory action, although not enough to reduce the volume of edema.

In tendons from the group treated only with laser therapy, the swelling reduction may be associated with laser action in improving local circulation, since according to Gur et al. ${ }^{18}$ promotes decrease of the clinical sign. Although the group that was maintained in rest received no treatment, the possibility of free movement inside the cage may also have been a positive factor to reduce swelling in these animals. On the other hand, the absence of difference between groups in the tendon transverse diameter, at 21 days after injury induction, suggests that the Achilles tendon of rats, injured according to methodology adopted in the present study is macroscopically repaired in only three weeks. This fast tendinopathy recovery was confirmed by biomechanical analysis, which revealed no difference between groups.

The absence sensitivity to pain in the physical evaluation performed 12 hours after surgery may be associated with the analgesic administered, which may have masked the pain condition. However, rats remained with no pain in the following evaluations. In groups that received laser therapy, this absence can be justified by the analgesic effect of the low-level laser, which may result in increased levels of endorphins, and therefore increased pain threshold ${ }^{19}$.

Despite the absence of sensitivity to pain, the possibility of discomfort of mechanical origin cannot be discarded, since the animals presented a discrete lameness during evaluation of the locomotor capacity. Another hypothesis is the fact that the scale used for evaluation of sensitivity to pain may not have been adequate for the kind of induced injury. This scale adopted was based on the assessment of abnormal pain-related sensation in rats with sciatic nerve injury. Minville et al. ${ }^{20}$ also used the same classification to verify the rat's response with fracture produced in the right tibia using a blunt guillotine to morphine or ketoprofen treatment. According to the authors, the scale was effective in the identification of pain, and the used drugs promoted dose-dependent analgesia. However, as the fracture was created with guillotine, it must have affected not only the bone tissue, but also the adjacent ones. In addition, periosteal injuries originating from orthopedic procedures cause greater pain severity in the postoperative period, than those in soft tissues ${ }^{21}$.

In fact, in our opinion, the scale used to evaluate the locomotor capacity of animals showed efficient. It was possible to notice the functional evolution of animals during bar walking, although the rats in group E presented lower locomotion capacity. According to Silva ${ }^{10}$, the scale allows to identify minimum changes, which are often imperceptible during evaluation of deambulation in the open field.

Despite the importance of eccentric exercise in tendinopathy recovery, eccentric contraction can promote micro-ruptures of the muscle fibers $^{22}$. Exercises were scheduled to begin 24 hours after injury induction aiming to standardize the time to begin the treatments, in order to minimize the risk factors that could compromise the interpretation of the obtained results. So, the protocol adopted in the present stu$d y$, with beginning of eccentric exercise 24 hours after induction of tendinopathy, did not promote complete recovery of the locomotor capacity of animals, as the group treated only with eccentric exercise moved with difficulty in the narrowest bars $(2.7$ and $1.7 \mathrm{~cm})$. However, when associated with laser therapy, the ability to move was greater than that of the groups $\mathrm{R}$ and $\mathrm{E}$. On the other hand, the time to start the activities was particularly important because low-level laser is recommended to be used within the first hours after tendon injury, due to its analgesic and anti-inflammatory effect. This moment, considered ideal, was also based on the protocol described by Nakamura et al. ${ }^{13}$, who observed beneficial effect of downhill running, when initiated 24 hours after surgical induction of tendinopathy in patellar tendon of rats. 
However, researchers have proved the efficiency of physical activity by histopathology, but not by biomechanical evaluation. Patellar and Achilles tendons are the anatomical structures most commonly affected by tendinopathy in humans ${ }^{23}$. Nevertheless, the patellar tendon is apparently more resistant ${ }^{24}$.

Kraux et al. ${ }^{24}$ emphasized the importance of eccentric as regards concentric exercise that, apparently, resulted in a tendon with superior biomechanical properties. On the other hand, considering speed (17 m/min), activity time (60 min/day) and evaluation period (5 weeks), used by these authors, the eccentric exercise protocol adopted in the present study does not seem to have been excessive. Furthermore, the animals were previously adapted, as in other study ${ }^{14}$. This adaptation process, which generally varies from one to two weeks, is considered fundamental ${ }^{25}$, since it possibly improves the performance of animals. Nevertheless, studies are still necessary to define the best moment for laser therapy and eccentric exercise for tendinopathy treatment.

The comparison of mean values of the biomechanical characteristics evaluated revealed no differences ( $p>0.05$ ) between groups. This result may be associated with the rat metabolism, which is considered "faster" than that of human ${ }^{26}$, which can result in a tendon healing more rapidly. Therefore, it is possible that the period of 21 days after injury for biomechanical analysis is too long to note difference between groups, since this period can be sufficient for physiologic healing of tendons. Despite this metabolism difference, rats are considered excellent experimental models for humans due to the anatomical and physiologic similarity. In addition, the resistance of these animals in comparison with other species $^{23}$ is a positive aspect to be considered in studies of this nature.

See et al. ${ }^{27}$ also observed no significant difference between groups in some biomechanical characteristics evaluated in Achilles tendons of Sprague-Dawley rats, surgically injured by partial rupture. The authors divided the animals in three groups, control (with injury and without treatment), exercised running, and a group submitted to swimming. Differences ( $p>0.05$ ) were not observed between groups for variables stiffness and load relaxation, when samples were analyzed 30 days after injury; however, the maximum load necessary for tendon rupture was greater $(p=0.015)$ in the group that performed exercise running, than in the control. In the present study, the maximum load value also was also greater in the group submitted to eccentric exercise, either combined (26.59 \pm 19.63$)$ or not $(25.47 \pm 20.10)$ with laser therapy, when compared with the group submitted to tendinopathy, but maintained at rest (20.53 \pm 6.09$)$. However, differently from the study of See et al. ${ }^{27}$, no significant difference was observed between groups to the characteristic maximum load. Conversely, it was noticed that, although it was not statistically different, the load necessary for the rupture of the injured and exercised tendons was lower than that required for uninjured tendons (34.33 \pm 11.68 ). However, this finding reinforces the conclusion that eccentric exercise treadmill walking initiated during the acute phase of induced tendinopathy, performed for 21 days after injury, gives the tendon more strength to support the load, compared to the injured but not exercised tendons.

There are different types of eccentric exercises: plyometric, isokinetic, as well as downhill running and downhill walking. In this last type, the muscles act against gravity to support the weight of the body and to absorb shock, which can result in muscle fatigue when in excess ${ }^{22}$. On the other hand, it is well-known that a repaired tendon will not behave like a healthy tendon biomechanically ${ }^{4}$. Other studies that performed biomechanical tests used a greater number of tendons per group (ranging from 5 to 11), than the amount used in the present study. Although some of them found statistically significant differences between groups ${ }^{27-28}$, others did not obtain positive effect of the studied treatment ${ }^{16,29}$.

Comparing the present results with those of Godbout et al. ${ }^{25}$ and of Eliasson et al. ${ }^{14}$ who also worked with the Achilles tendon of Wistar rats submitted to exercise, the mean values obtained for maximum load in the group that performed physical activity combined $(26.59 \pm 19.63 \mathrm{~N})$ or not $(25.47 \pm 20.10 \mathrm{~N})$ with laser therapy were below those found by Godbout et al. ${ }^{25}$ (approximately $30 \mathrm{~N}$ ). Conversely, maximum load values were maintained above those reported by Eliasson et al. ${ }^{14}$ in rats exercised in treadmill from day 8 after Achilles tendon transection, which was only $17 \mathrm{~N}$. These data show that the results with eccentric exercise are contradictory, and therefore, reinforce the necessity of better definition of the ideal moment for initiation of exercise, as well as speed, duration, and frequency of treatment. In the group treated with laser only a load of $15.31 \mathrm{~N}$ was required to rupture the tendon. This result was not satisfactory, as it suggests tendon fragility. Different results were reported by Nouruzian et al. ${ }^{28}$ after Achilles tendon treatment in diabetic rats submitted to tenotomy and helium-neon ( $\mathrm{He}-\mathrm{Ne}$ ) laser treatments, at 2.9, 4.3 or $11.5 \mathrm{~J}$ energy densities and $632.8 \mathrm{~nm}$ wavelength, beginning immediately after surgery. According to the authors, the treatment at $2.9 \mathrm{~J}$ promoted increase $(\mathrm{p}<0.05)$ of tendon strength and maximum stress. The strain rate used by these authors during the biomechanical analysis was twofold $(1 \mathrm{~mm} / \mathrm{s})$ the one used in the present study $(0.5$ $\mathrm{mm} / \mathrm{s}$ ), which was based on that described by Sardenberg et al. ${ }^{16}$ There is no standardization of this characteristic in studies that performed biomechanical analysis in rat tendons. There are studies that used from $0.1 \mathrm{~mm} / \mathrm{s}^{15}$ up to $1 \mathrm{~mm} / \mathrm{s}^{22}$. It is believed that this characteristic could interfere in the results obtained during the biomechanical evaluation of the tendon. Therefore, this variable should be standardized.

The energy density (3J) used in the present study was very close to that described as adequate (2.9 J) by Nouruzian et al. ${ }^{28}$, for Achilles tendon treatment of diabetic rats after tenotomy. However these authors used He-Ne laser, and not GaAs. This concentration of $3 \mathrm{~J}$ is the recommended one by the World Association for Laser Therapy (WALT) when $904 \mathrm{~nm}$ wavelengths are employed for Achilles tendon treatment. However, the laser did not promote tendon healing improvement, when analyzed by histopathology ${ }^{7-8}$, when GaAs and/or aluminum gallium indium phosphorus laser were used. In the animals of the present study, which belong to the group treated only with laser, the tendon ruptured with a lower maximum load, compared with the other groups with and without injury $(p=0.4379)$. The same occurred in a study carried out by Marcos et al. ${ }^{30}$, where tendons treated with laser at $3 \mathrm{~J}$ and $810 \mathrm{~nm}$ ruptured with a similar load to those animals from control groups (saline solution) differently from the treated group. On the other hand, the tendons treated with $1 \mathrm{~J}$ ruptured when submitted to a load similar to that required to rupture healthy tendons. Thus, the energy density of 3J may not be adequate even being the commonly used dose in studies for treatment of induced tendon injuries ${ }^{8,31}$

Joensen et al. ${ }^{29}$ also revealed no difference ( $\left.p>0.05\right)$ between treated and control (contralateral) groups, in the biomechanical property (maximal load) of rat tendons injured by a mini guillotine, and treated with GaAs laser (3 J/904 nm/30 min). Ultrasonography evaluation revealed difference $(p<0.05)$ in tendon thickness between treated and control groups. According to the authors, during the first two weeks after tenotomy, tendons usually break when subjected to a load below that necessary for a healthy tendon. This may have occurred in this study, since the tendons treated only with laser ruptured when submitted to the small load of $15.31 \pm 7.97 \mathrm{~N}$. The amount suggested by the WALT must be adjusted for the species to be treated. An inappropriate energy density may cause an undesired result; high doses in soft tissues may inhibit tissue healing process, whereas low amounts may not promote the desired effect. 
This was a controlled study conducted over a period of 21 days after induced tendinopathy of the Achilles tendon of Wistar rats. The adopted laser therapy protocol followed the recommendations of the WALT. The number of animals per group, and the performance of physical activity $24 \mathrm{~h}$ after injury are in agreement with previously used protocols, although represent some of the limitations of the study. Moreover, despite the amount of animals being a limiting factor in this research does not necessarily interfere with the results obtained.

\section{CONCLUSIONS}

Laser therapy associated with eccentric exercise downhill walking, started 24 hours after Achilles tendinopathy, surgically induced by compression and scarification, do not result in a biomechanically as resistant or elastic as a healthy tendon. On the other hand, it also does not influence negatively in the tendon structure and function. In addition, the extension and maximum load necessary for the rat Achilles tendon to rupture, three weeks after tendinopathy induced by compression and scarification, does not differ from that required to rupture a physiologically healthy tendon, tested at $0.5 \mathrm{~mm} / \mathrm{s}$ speed.

\section{ACKNOWLEDGEMENTS}

The authors thank Coordenação de Aperfeiçoamento de Pessoal de Nivel Superior (CAPES) for grating scholarships, the Fundação de Amparo à Pesquisa do Estado de Minas Gerais (FAPEMIG) for the financial support, as well as Conselho Nacional de Desenvolvimento Científico e Tecnológico (CNPq) for providing research fellowships (process number 472832/2012-3).

All authors have declared there is not any potential conflict of interests concerning this article.

\section{REFERENCES}

1. Wang JH-C, Guo Q, Li B. Tendon biomechanics and mechanobiology - a minireview of basic concepts and recent advancements. J Hand Ther. 2012;25(2):133-40.

2. Tardioli A, Malliaras $P$, Maffulli N. Immediate and short-term effects of exercise on tendon structure: biochemical, biomechanical and imaging responses. Br Med Bull. 2012;103(1):169-202.

3. Abate M, Schiavone C, Salini V, Andia I. Occurrence of tendon pathologies in metabolic disorders. Review. Rheumatol. 2013;52(4):599-608.

4. Hope M, Saxby TS. Tendon healing. Foot ankle Clin. 2007;12(4):553-67.

5. Aras MH, Omezli MM, Güngörmüs M. Does low-level laser therapy have an antianesthetic effect? A review. Photomed Laser Surg. 2010;28(6)719-22.

6. Dogan SK, Ay S, Deniz E. The effectiveness of low laser therapy in subacromial impingement syndrome: a randomized placebo controlled double-blind prospective study. Clin Sci. 2010; 65(10):1019-22.

7. Salate ACB, Barbosa G, Gaspar P, Koeke PU, Parizotto NA, Benze BG, et al. Effect of In-Ga-Al-P Diode laser irradiation on angiogenesis in partial ruptures of Achilles tendon in rats. Photomed Laser Surg. 2005;23(5):470-575.

8. Arruda ERB, Rodrigues NC, Taciro C, Parizotto NA. Influência de diferentes comprimentos de onda da laserterapia de baixa intensidade na regeneração tendínea de rato após tenotomia. Rev Bras Fisiot. 2007;11(4):283-8.

9. Attal N, Jazat F, Kayser V, Guilbaud G. Further evidence for "pain-related" behaviours in a model of unilateral peripheral mononeuropathy. Pain. 1990;41(2):235-51.

10. Silva CMO. Efeito da prednisona em lesão medular aguda experimental em ratos (Rattus novergicus). Dissertation, 46p. Escola de Veterinária, Universidade Federal de Minas Gerais, 2008.

11. Silva MO, Costa MBM, Borges APB, Dornas RF, Moreira JCL, Souza MV. Indução de tendinopatia em ratos Wistar: modelo experimental. Rev Acad Ciênc Agrár Ambient. 2013;11(3):275-82.

12. Silva JMN, Carvalho JP, Moura Júnior MJ. Estudo morfométrico da terapia LED de baixa potência em tendinite de ratos. Fisioter Pesqui. 2011;18(4):365-70.

13. Nakamura K, Kitaoka K, Tomita K. Effect of eccentric exercise on healing process of injured patellar tendon in rats. J Orthop Sci. 2008;13(4):371-8

14. Eliasson P, Andersson T, Aspenberg P. Achilles tendon healing in rats is improved by intermittent mechanical loading during the inflammatory phase. J Orthop Res. 2012;30(2):274-9.

15. Orhan Z, Ozturan K, Guven A, Cam K. The effect of extracorporeal shock waves on a rat model of injury to tendo Achillis: a histological and biomechanical study. J Bone Joint Surg Br. 2004;86(4):613-8.

16. Sardenberg T, Muller SS, Garms LZ, Miduati FB. Efeito tardio e imediato da sutura em tendão extrassinovial íntegro: estudo biomecânico em ratos. Rev Bras Ortop. 2011;46(3):305-8.
17. Lana AC, Paulino CA, Gonçalves ID. Efeitos dos exercícios físicos sobre o edema inflamatório agudo em ratos Wistar. Rev Bras Med Esporte. 2008;14(1):33-7.

18. Gur A, Sarac AJ, Cevik R, Altindag O, Sarac S. Efficacy of 904 nm gallium arsenide low level laser therapy in the management of cronic myofascial pain in the neck: a double-blind and randomized-controlled Trial. Lasers Surg Med. 2004;35(3):229-35.

19. Moshkovska T, Mayberry J. It is time to test low level laser therapy in Great Britain. Postgrad Med J. 2005;81(957):436-41.

20. Minville V, Laffosse J-M, Fourcade O, Girolami J-P. Mouse modelo fracture pain. Anesth. 2008;108(3):467-72.

21. Oliva VNLS, Maia LAA, Silva BM, Saito LM, Perri SHV. Avaliação clínica de diferentes antiinflamatórios não esteróides na analgesia pós-operatória de cirurgias ortopédicas em cães. Clin Vet. 2004;50:42-54

22. Clebis NK, Natali MJM. Lesões musculares provocadas por exercícios excêntricos. Rev Bras Ciên Mov. 2001;9(4):47-53.

23. Lui PPY, Maffulli N, Smith RKW. What are the validated animal models for tendinopathy? Review. Sand J Med Sci Sports 2011;21(1):213-7.

24. Kaux J-F, Drion P, Libertiaux V, Colige A, Hoffmann A, Nusgens B, et al. Eccentric training improves tendon biomechanical properties: a rat model. J Orthop Res. 2012; 31(1):119-24.

25. Godbout C, Ang O, Frenette J. Early voluntary exercise does not promote healing in a rat model of Achilles tendon injury. J Appl Physiol. 2006; 101(6):1720-6.

26. Fagundes DJ, Taha MO. Modelo animal de doença: critérios de escolha e espécies de animais de uso corrente. Acta Cir Bras. 2004;19(1):59-65.

27. See EKN, Ng GYF, Ng COY, Fung DTC. Running exercise improve the strength of a partially ruptured Achilles tendon. Br J Sports Med. 2004; 38:597-600.

28. Nouruzian M, Alidoust M, Bayat M, Bayat M, Akbari M. Effect of low-level laser therapy on healing of tenotomized Achilles tendon in streptozotocin-induced diabetic rats. Lasers Surg Med. 2013;28(2):399-405

29. Joensen J, Gjerdet NR, Hummelsund S, Iversen V, Lopes-Martins RAB, Bjordal JM. An experimental study of low-level laser therapy in rat Achilles tendon injury. Lasers Med Sci. 2012;27(1):103-11.

30. Marcos RL, Leal-Junior ECP, Arnold G, Magnenet V, Rahouadj R, Wang X, et al. Low-level laser therapy in collagenase-induced Achilles tendinitis in rats: analyses of biochemical and biomechanical aspects. J Orthop Res. 2012; 30(12):1945-51.

31. Lima JGM, Oliveira Filho GR, Lima MTBRM, Ferreira AS, Silva JG. Influence of low intensity laser therapy (AsGa) on the cicatrization process of mechanic tendon injury in Wistar rats. Laser Physics 2012; 22(9):1445-8. 